\title{
Study of conditions of gas- discharge synthesis of Zinc oxide nanostructures under automatic UV-irradiation of the substrate by plasma
}

\author{
Uzhhorod National University, Uzhhorod, Ukraine, alexsander.shuaibov@uzhnu.edu.ua
}

\begin{abstract}
The spectroscopic characteristics of a bipolar, overstressed discharge of nanosecond duration between zinc electrodes in oxygen at a pressure $\mathrm{p}\left(\mathrm{O}_{2}\right)=13.3 \mathrm{kPa}$ are presented. In the process of microexplosions of inhomogeneities on the working surfaces of the electrodes in a strong electric field, zinc vapor is introduced into the discharge gap. This creates the prerequisites for the formation of zinc oxide molecules and clusters in the plasma and the synthesis of thin island zinc oxide films, which can be deposited on a dielectric substrate installed near the center of the discharge gap.

The spectral characteristics of the discharge were investigated from the central part of the discharge gap 2 $\mathrm{mm}$ in size. The main excited components of the plasma of a vapor-gas mixture based on zinc and oxygen were established at high values of the parameter $\mathrm{E} / \mathrm{N}$ (where $\mathrm{E}$ is the electric field strength; $\mathrm{N}$ is the total concentration of particles in the plasma), which, when deposited outside the discharge plasma, can lead to the formation of fine nanostructured films based on zinc oxide.
\end{abstract}

Key words: intense nanosecond discharge, oxygen, zinc, radiation spectrum, plasma.

Received 9 July 2021; Accepted 13 November 2021.

\section{Introduction}

The optical characteristics of a nanosecond discharge in air at atmospheric pressure at a distance between the metal electrodes $\mathrm{d}=1-2 \mathrm{~cm}$ are determined in the UV range of the emission spectrum of the bands of the second positive system of the nitrogen molecule (280$390 \mathrm{~nm}$ ), hydroxyl radicals (OH), nitrogen oxides (NO), bands of carbon nitride $(\mathrm{CN})$, as well as individual spectral lines of atoms and singly charged ions of nitrogen and oxygen [1]. When the distance between the electrodes decreases to $0.5-2.0 \mathrm{~mm}$, spectral lines of atoms and ions of the electrode material (copper, iron, zinc and others) appear in the plasma radiation spectra of such nanosecond discharges [2]. When operating in the mode of overvoltage of the interelectrode gap, runaway electrons are recorded in such a plasma, which pass into the mode of continuous acceleration with energies at the level of the amplitude of the voltage pulse applied to the discharge gap [3, 4]. Under the action of a beam of runaway electrons and the accompanying X-ray radiation, which play the role of preionization, a spatial homogeneous discharge is formed in the discharge gaps of the "sphere - sphere" type with an inhomogeneous distribution of the electric field strength, which can be used to develop new UV lamps with a small volume plasma medium $\left(\mathrm{V}<10 \mathrm{~mm}^{3}\right)$. Such short pulse UV "spot" lamps are necessary for spectroscopy, photochemistry and photobiology applications.

Some optical and energy characteristics of "point" UV lamps on metal vapors, from which the electrodes of an overstressed unipolar nanosecond discharge are made, are given in [5], and for the corresponding bipolar discharge in [6]. The use of a bipolar discharge makes it possible to decrease the impulse voltage relative to the grounded parts of the discharge device, as well as to use the electrode material more evenly, which is spent on the formation of ectons and is accompanied by the emission 
of vapors of the electrode material into the plasma [7].

Since this discharge occurred in the vapors of the electrode material and the degradation products of air molecules, the synthesis of island film nanostructures based on copper and zinc oxides was observed, which can be synthesized (outside the plasma) on a dielectric substrate [8-10].

Synthesis of such nanostructures in the field of UV radiation deserves special attention. Thus, in [11], during the synthesis of film nanostructures of zinc oxide in the form of a set of nanopillars with continuous illumination of the substrate during synthesis by UV radiation from a mercury lamp, a decrease in the resistance of film nanostructures was obtained. A study of the emission characteristics of an overstressed bipolar discharge in air and helium at atmospheric pressure between two zinc electrodes showed that it is a selective source of radiation in the spectral range 200-230 [12, 13], which can be used for automatic illumination of a film of zinc oxide nanostructures in the process its synthesis.

When an overstressed nanosecond discharge is ignited between copper or zinc electrodes, its plasma acts not only as a source of bactericidal UV radiation $(\Delta \lambda=$ 200-280 nm) [14], but also a stream of copper or zinc oxide nanoparticles, which have strong antibacterial properties [15].

To optimize the synthesis of film nanostructures based on zinc oxide, it is important to optimize the operation of such a gas-discharge reactor using not only air at atmospheric pressure, but also other oxygencontaining gases, especially with a decrease in the working gas pressure, which will increase the degree of overvoltage of the discharge gap.

The article presents the results of a spectroscopic study of an overstressed bipolar discharge of nanosecond duration between zinc electrodes in medium pressure oxygen, which can be used both as UV bactericidal radiation and for the synthesis of film nanostructures of zinc oxide upon automatic irradiation of a substrate with a film with UV radiation.

\section{Methods and experimental technique}

The study of the characteristics of an overstressed nanosecond discharge was carried out on the experimental stand described in [13]. The block diagram of the discharge module is shown in Fig. 1. A diagram of the discharge cell is given in [16]. An intense nanosecond discharge between zinc electrodes was ignited in a sealed Plexiglas chamber. The distance between the electrodes was $\mathrm{d}=2$ or $7 \mathrm{~mm}$.

To ignite the discharge, high voltage bipolar pulses with a duration of 50-150 ns and an amplitude of \pm (2040) $\mathrm{kV}$ were applied to the electrodes of the discharge cell. The voltage pulse repetition rate was chosen equal to $80-150 \mathrm{~Hz}$, since at high frequencies there was a significant heating of the electrode system and the discharge chamber. Oscillograms of voltage pulses across the discharge gap and oscillograms of current pulses were recorded using a broadband capacitive voltage divider, a Rogowski coil, and a 6LOR-04 broadband oscilloscope.

The discharge gap was overstressed, which created favorable conditions for the formation of a high-energy "runaway" electron beam and accompanying X-ray radiation $[3,4]$.

Plasma radiation, which was recorded in the spectral range $\lambda=196-663 \mathrm{~nm}$, entered the entrance slit of a spectrometer with a diffraction grating 1200 line/mm. A

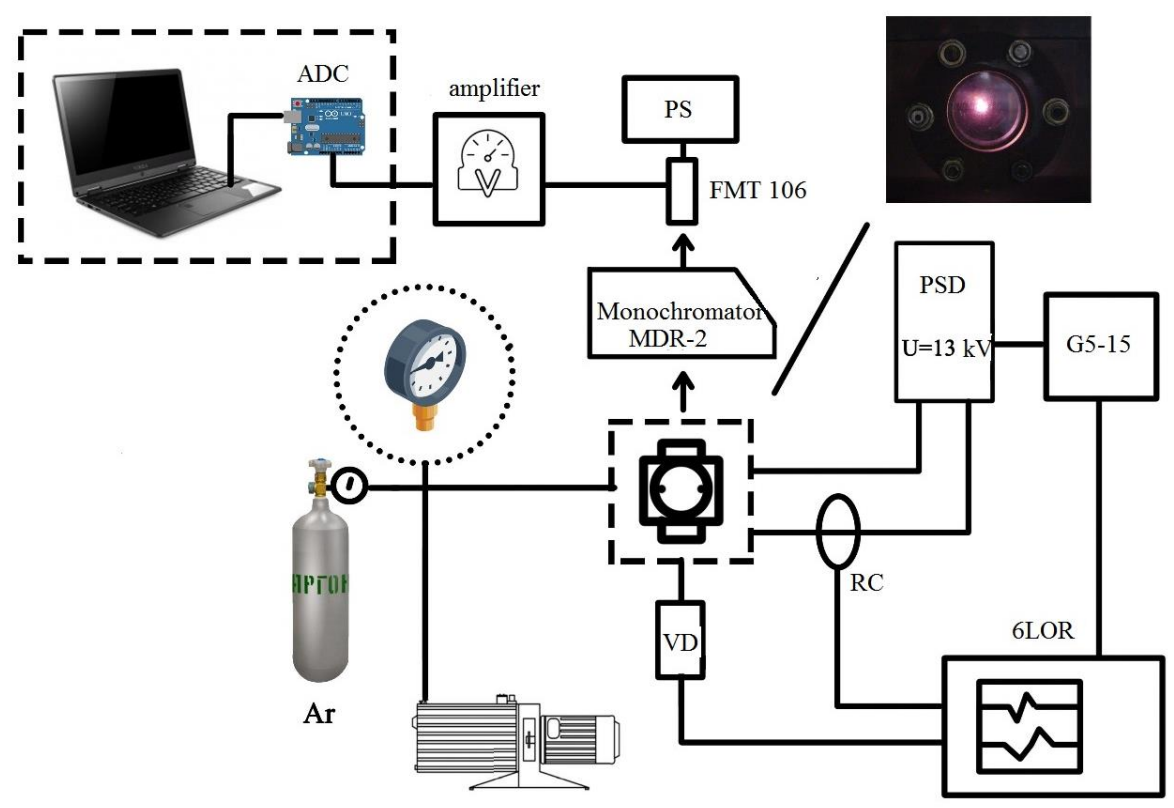

Fig.1. Diagram of an experimental setup for studying overstressed nanosecond discharge in gases: PSD discharge power supply; FMT 106 - photoelectric multiplier tube; PS- power supply unit; ADC - analog-to-digital signal converter; RC - Rogovsky belt; VD - voltage divider to determine the voltage drop in the circuit; G5-15 pulse generator; 6LOR is a broadband oscilloscope. 
FEU-106 photomultiplier tube connected to a dc amplifier was used at the output of the spectrometer to detect radiation. The signal from the amplifier was fed to an analog-to-digital converter and then fed to a personal computer for processing.

The discharge chamber was evacuated by a foreline pump to a residual pressure of $10 \mathrm{~Pa}$, and then oxygen was filled in the chamber to a pressure of $13.3 \mathrm{kPa}$. The diameter of the cylindrical metal electrodes was $5 \mathrm{~mm}$, and the radius of curvature of their working end surface was the same and equal to $3 \mathrm{~mm}$. The discharge volume depended on the voltage pulse repetition rate. The "point discharge" mode was achieved only at voltage pulse repetition rates in the range $\mathrm{f}=40-150 \mathrm{~Hz}$.

\section{Spatial, electrical and spectral characteristics}

Fig. 2 presents the time-averaged images of a bipolar overstressed nanosecond discharge in oxygen at different distances between the electrodes, which were obtained with a time delay of $\approx 1 \mathrm{~s}$.

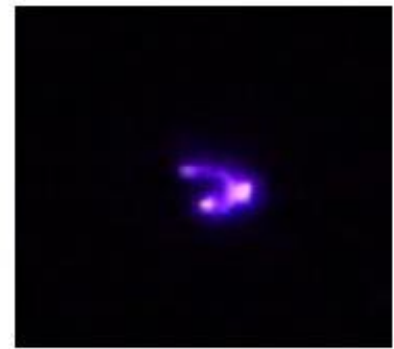

a)

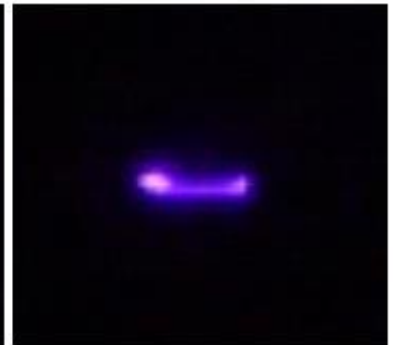

б)
Fig. 2. Time-averaged $(t=1 \mathrm{~s})$ images of an overstressed nanosecond discharge in oxygen $(p=13.3$ $\mathrm{kPa}$ ) at a distance between the electrodes $\mathrm{d}=2$ (a) and 7 (b) $\mathrm{mm}$.

At an oxygen pressure of $13.3 \mathrm{kPa}$ and $\mathrm{d}=2 \mathrm{~mm}$, the discharge that was investigated looked like a bright central part with a diameter of about $2 \mathrm{~mm}$, which was equal to the interelectrode distance and a series of weaker plasma jets that escaped from the central part. With an increase in the distance between the electrodes to $7 \mathrm{~mm}$, the brightest part of the discharge plasma was concentrated at the rounded working surface of the zinc electrodes, which were covered by a thin, less bright plasma channel. The main reasons for the appearance of the diffuse glow of the discharge between the electrodes $(\mathrm{d}=2 \mathrm{~mm})$ and at the surface of the electrodes at a considerable distance between them $(\mathrm{d}=7 \mathrm{~mm})$ can be beams of "runaway electrons" and the accompanying Xray radiation $[3,4]$.

Oscillograms of voltage, current, and pulsed power for an overstressed nanosecond discharge between zinc or copper electrodes (at $\mathrm{p}\left(\mathrm{O}_{2}\right)=13.3 \mathrm{kPa} ; \mathrm{d}=2 \mathrm{~mm}$ ) had the same form as in the same discharge in air between zinc electrodes, copper or chalcopyrite $[13,16]$.

Oscillograms of voltage and current were in the form of oscillations decaying in time with a duration of about 7-10 ns, which is due to the mismatch of the output resistance of the high-voltage modulator with the load resistance. The total duration of the voltage oscillations across the gap and the discharge current reached $400 \mathrm{~ns}$ with the duration of individual voltage oscillations 7-10 $\mathrm{ns}$, and the current oscillations had a duration of $\approx 70 \mathrm{~ns}$. For a nanosecond discharge, it was investigated that the amplitude of the largest voltage drop at the electrodes was achieved at the initial stage of the discharge and was $\approx+7-8 \mathrm{kV}$, and the current was $\pm 140-160 \mathrm{~A}$. By graphically multiplying the oscillograms of the current and voltage pulse, the pulsed power of the discharge was obtained, the integral from which in time within the duration of a nanosecond discharge made it possible to establish the energy contribution to the plasma in one discharge pulse. The magnitude of the pulse discharge power reached (0.5-0.6) MW, which ensured an energy contribution to the plasma in one discharge pulse at a level of up to $30 \mathrm{~mJ}$. With an increase in the interelectrode distance to $7 \mathrm{~mm}$, the voltage drop across the electrodes and the current value were, respectively, up to $+(0.7-0.8) \mathrm{kV}$ and $\pm(90-100) \mathrm{A}$. The pulsed power at $\mathrm{d}=7 \mathrm{~mm}$ reached $0.15 \mathrm{MW}$, which ensured the energy contribution to the plasma in one discharge pulse at a level of up to $20 \mathrm{~mJ}$.

The emission spectrum of an overstressed nanosecond discharge in oxygen is shown in Fig. 3, and the results of identification of spectral lines and bands are summarized in the table. When decoding the radiation spectrum, reference books were used $[17,18]$.

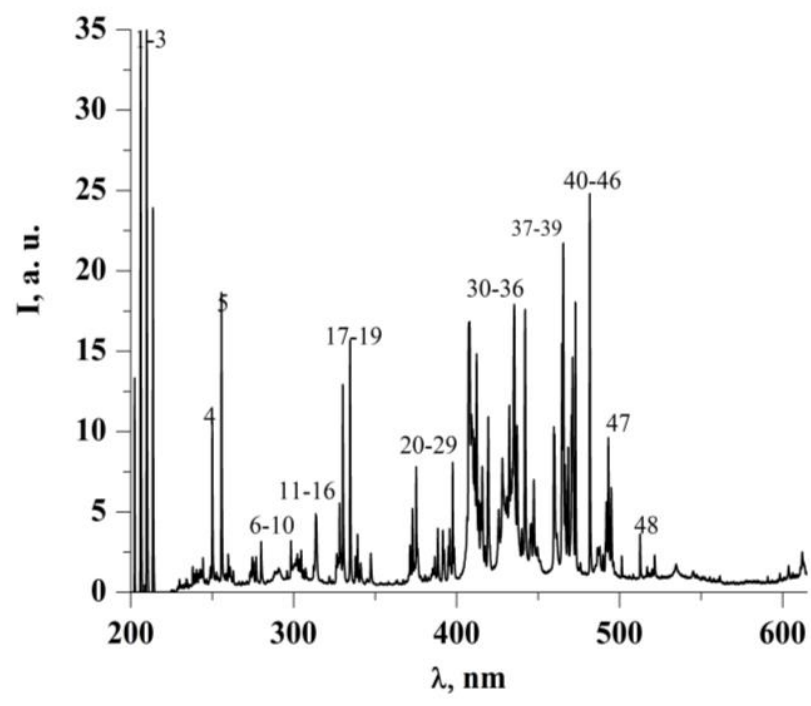

Fig. 3. The emission spectrum of the plasma of a bipolar, overstressed discharge in oxygen of nanosecond duration $\left(\mathrm{p}\left(\mathrm{O}_{2}\right)=13.33 \mathrm{kPa} ; \mathrm{d}=2 \mathrm{~mm}\right)$.

The main spectral lines of the plasma radiation were the spectral lines of the atom and the singly charged zinc ion, which are located in the spectral range of $206-280$ $\mathrm{nm}$. The most intense from the ionic spectral lines of zinc were: $206.20 ; 209.99 \mathrm{~nm} \mathrm{Zn} \mathrm{II,} \mathrm{and} \mathrm{from} \mathrm{atomic} \mathrm{lines} \mathrm{-}$ $213.85 \mathrm{~nm} \mathrm{Zn} \mathrm{I,} \mathrm{which} \mathrm{correlates} \mathrm{with} \mathrm{the} \mathrm{spectral}$ characteristics of the lamp [19]. Compared with the data of [19], the UV radiation spectrum in these regions included significantly more intense spectral lines of the atom and singly charged zinc ion. 
Table 1

Results of spectrum identification (Fig. 3) of plasma radiation of an overstressed nanosecond discharge in oxygen.

\begin{tabular}{|c|c|c|c|c|c|c|c|}
\hline № & $\lambda$ tab., $\mathbf{n m}$ & $\begin{array}{l}\text { I exp., } \\
\text { a.u. }\end{array}$ & Object & Elow., $\mathrm{eV}$ & Eup., $\mathrm{eV}$ & Lower term & Upperterm \\
\hline 1 & 206.20 & 34.23 & Zn II & 0 & 6.01 & $3 d^{10} 4 s^{2} S_{1 / 2}$ & $3 d^{10} 4 p^{2} P^{0}{ }_{1 / 2}$ \\
\hline 2 & 209.99 & 35.78 & $\mathrm{Zn} \mathrm{II}$ & 6.11 & 12.02 & $3 d^{10} 4 p^{2} P_{3 / 2}^{0}$ & $3 d^{10} 4 d^{2} D_{5 / 2}$ \\
\hline 3 & 213.85 & 23.93 & $\mathrm{Zn} \mathrm{I}$ & 0 & 5.79 & $3 d^{10} 4 s^{2}{ }^{1} S_{0}$ & $3 \mathrm{~d}^{10} 4 \mathrm{~s} 4 \mathrm{p}^{2} \mathrm{P}^{0}{ }_{1}$ \\
\hline 4 & 250.19 & 10.57 & $\mathrm{Zn} \mathrm{I}$ & 6.01 & 10.96 & $3 d^{10} 4 p^{2} P_{1 / 2}^{0}$ & $3 \mathrm{~d}^{10} 5 \mathrm{~s}^{2} \mathrm{~S}_{1 / 2}$ \\
\hline 5 & 255.79 & 18.40 & Zn II & 6.11 & 10.96 & $3 d^{10} 4 p^{2} P^{0}{ }_{3 / 2}$ & $3 d^{10} 5 s^{2} S_{1 / 2}$ \\
\hline 6 & 258.24 & 2.47 & Zn I & 4.02 & 8.82 & $3 d^{10} 4 s 4 p^{3} P_{1}^{0}$ & $3 d^{10} 4 s 6 d^{3} D_{2}$ \\
\hline 7 & 267.05 & 0.81 & $\mathrm{Zn} \mathrm{I}$ & 4.00 & 8.64 & $3 \mathrm{~d}^{10} 4 \mathrm{~s} 4 \mathrm{p}^{3} \mathrm{P}_{0}^{0}$ & $3 d^{10} 4 s^{2} s^{3} S_{1}$ \\
\hline 8 & 273.32 & 1.36 & O II & 25.28 & 29.82 & $2 \mathrm{~s}^{2} 2 \mathrm{p}^{2}\left({ }^{3} \mathrm{P}\right) 3 \mathrm{p}^{2} \mathrm{~S}_{1 / 2}$ & $2 \mathrm{~s}^{2} 2 \mathrm{p}^{2}\left({ }^{3} \mathrm{P}\right) 4 \mathrm{~s}^{2} \mathrm{P}_{3 / 2}$ \\
\hline 9 & 277.09 & 2.4 & $\mathrm{Zn} \mathrm{I}$ & 4.02 & 8.50 & $3 \mathrm{~d}^{10} 4 \mathrm{~s} 4 \mathrm{p}^{3} \mathrm{P}^{0}{ }_{1}$ & $3 d^{10} 4 s 5 d^{3} D_{1}$ \\
\hline 10 & 280.08 & 3.4 & $\mathrm{Zn} \mathrm{I}$ & 4.07 & 8.50 & $3 \mathrm{~d}^{10} 4 \mathrm{~s} 4 \mathrm{p}^{3} \mathrm{P}_{2}{ }_{2}$ & $3 d^{10} 4 s_{5} d^{3} D_{3}$ \\
\hline 11 & 298.04 & 3.31 & O II & 28.82 & 32.98 & $\begin{array}{c}2 \mathrm{~s}^{2} 2 \mathrm{p}^{2}(3 \mathrm{P}) 3 \mathrm{~d} \\
{ }^{4} \mathrm{P}_{5 / 2}\end{array}$ & $\begin{array}{c}2 \mathrm{~s}^{2} 2 \mathrm{p}^{2}(3 \mathrm{P}) 5 \mathrm{f} \\
\mathrm{F}^{2}[4]^{0} 7 / 2\end{array}$ \\
\hline 12 & 302.01 & 2.26 & O II & 28.83 & 32.93 & $\begin{array}{c}2 \mathrm{~s}^{2} 2 \mathrm{p}^{2}(3 \mathrm{P}) 3 \mathrm{~d} \\
{ }^{4} \mathrm{P}_{3 / 2}\end{array}$ & $\begin{array}{c}2 \mathrm{~s}^{2} 2 \mathrm{p}^{2}(3 \mathrm{P}) 5 \mathrm{f} \quad \mathrm{D} \\
{ }^{2}[3]^{0}{ }_{5 / 2}\end{array}$ \\
\hline 13 & 304.71 & 2.82 & O II & 28.88 & 32.95 & $2 \mathrm{~s}^{2} 2 \mathrm{p}^{2}\left({ }^{3} \mathrm{P}\right) 3 \mathrm{~d}^{2} \mathrm{~F}_{7 / 2}$ & $\begin{array}{c}2 \mathrm{~s}^{2} 2 \mathrm{p}^{2}\left({ }^{3} \mathrm{P}\right) 5 \mathrm{f} \\
\mathrm{D}^{2}[2]^{\circ}{ }^{\circ} / 2\end{array}$ \\
\hline 14 & 307.206 & 1.42 & $\mathrm{Zn} \mathrm{I}$ & 4.07 & 8.11 & $3 \mathrm{~d}^{10} 4 \mathrm{~s} 4 \mathrm{p}^{3} \mathrm{P}_{2}^{0}$ & $3 d^{10} 4 s 6 s^{3} S_{1}$ \\
\hline 15 & 313.60 & 4.71 & $\mathrm{~N}_{2}$ & \multicolumn{4}{|c|}{ Second positive system $\mathrm{C}^{3} \Pi_{\mathrm{u}}{ }^{+}-\mathrm{B}^{3} \Pi_{\mathrm{g}}{ }^{+}(2 ; 1)$} \\
\hline 16 & 327.75 & 5.62 & O II & 25.83 & 29.61 & $\begin{array}{c}2 s^{2} 2 p^{2}\left({ }^{3} \mathrm{P}\right) \\
3 p 4 \mathrm{P}^{0}\end{array}$ & $2 \mathrm{~s}^{2} 2 \mathrm{p}^{2}\left({ }^{3} \mathrm{P}\right) 4 \mathrm{~s} 4 \mathrm{P}_{5 / 2}$ \\
\hline 17 & 329.49 & 12.89 & O II & 25.83 & 29.59 & $2 \mathrm{~s}^{2} 2 \mathrm{p}^{2}\left({ }^{3} \mathrm{P}\right) 3 \mathrm{p}^{4} \mathrm{P}_{3 / 2}^{\circ}$ & $2 s^{2} 2 p^{2}\left({ }^{3} \mathrm{P}\right) 4 s^{4} \mathrm{P}_{3 / 2}$ \\
\hline 18 & 334.50 & 15.89 & $\mathrm{Zn} \mathrm{I}$ & 4.07 & 7.78 & $3 \mathrm{~d}^{10} 4 \mathrm{~s} 4 \mathrm{p}^{3} \mathrm{P}_{2}^{\circ}$ & $3 d^{10} 4 s 4 d^{3} D_{3}$ \\
\hline 19 & 339.02 & 3.57 & O II & 25.28 & 28.94 & $\begin{array}{c}2 \mathrm{~s}^{2} 2 \mathrm{p}^{2}\left({ }^{3} \mathrm{P}\right) 3 \mathrm{p} \\
2 \mathrm{~S}^{0}{ }_{1 / 2}\end{array}$ & $\begin{array}{c}2 \mathrm{~s}^{2} 2 \mathrm{p}^{2}\left({ }^{3} \mathrm{P}\right) \\
3 \mathrm{~d} 2 \mathrm{P}_{3 / 2}\end{array}$ \\
\hline 20 & 340.72 & 1.95 & O II & 28.50 & 32.14 & $\begin{array}{c}2 \mathrm{~s}^{2} 2 \mathrm{p}^{2}\left({ }^{1} \mathrm{D}\right) 3 \mathrm{p} \\
2 \mathrm{D}^{0}{ }_{5 / 2}\end{array}$ & $2 s^{2} 2 p^{2}\left({ }^{1} D\right) 4 s^{2} D_{3 / 2}$ \\
\hline 21 & 347.49 & 2.40 & O II & 25.28 & 28.85 & $2 \mathrm{~s}^{2} 2 \mathrm{p}^{2}\left({ }^{3} \mathrm{P}\right) 3 \mathrm{p}^{2} \mathrm{~S}_{1 / 2}^{\circ}$ & $2 s^{2} 2 p^{2}\left({ }^{3} P\right) 3 d^{4} D_{1 / 2}$ \\
\hline 22 & 371.27 & 2.98 & O II & 22.96 & 26.30 & $2 s^{2} 2 p^{2}\left({ }^{3} P\right) 3 s^{4} P_{1 / 2}$ & $2 s^{2} 2 p^{2}\left({ }^{3} P\right) 3 p^{4} S^{\circ}{ }_{3 / 2}$ \\
\hline 23 & 374.94 & 7.90 & O II & 23.00 & 26.30 & $3 \mathrm{~s}^{4} \mathrm{P}_{5 / 2}$ & $3 p{ }^{4} S_{0}$ \\
\hline 24 & 386.34 & 2.21 & O II & 25.64 & 28.85 & $\begin{array}{c}2 \mathrm{~s}^{2} 2 \mathrm{p}^{2}\left({ }^{3} \mathrm{P}\right) 3 \mathrm{p} \\
4 \mathrm{D}^{0}{ }_{5 / 2}\end{array}$ & $2 \mathrm{~s}^{2} 2 \mathrm{p}^{2}\left({ }^{3} \mathrm{P}\right) 3 \mathrm{~d} 4 \mathrm{D}_{7 / 2}$ \\
\hline 25 & 388.21 & 4.07 & O II & 25.66 & 28.85 & $\begin{array}{c}2 \mathrm{~s}^{2} 2 \mathrm{p}^{2}\left({ }^{3} \mathrm{P}\right) 3 \mathrm{p} \\
4 \mathrm{D}^{0}{ }_{7 / 2}\end{array}$ & $2 \mathrm{~s}^{2} 2 \mathrm{p}^{2}\left({ }^{3} \mathrm{P}\right) \quad 3 \mathrm{~d}^{4} \mathrm{D}_{7 / 2}$ \\
\hline 26 & 391.21 & 3.93 & O II & 25.66 & 28.82 & $\begin{array}{c}2 \mathrm{~s}^{2} 2 \mathrm{p}^{2}\left({ }^{1} \mathrm{D}\right) \\
3 \mathrm{~s}^{2} \mathrm{D}_{3 / 2}\end{array}$ & $2 \mathrm{~s}^{2} 2 \mathrm{p}^{2}\left({ }^{1} \mathrm{D}\right) \quad 3 \mathrm{p}^{2} \mathrm{P}^{0}{ }_{3 / 2}$ \\
\hline 27 & 395.46 & 3.97 & O I & 10.98 & 14.12 & $\begin{array}{c}2 s^{2} 2 p^{3}\left({ }^{4} S^{\circ}\right) \\
3 p^{3} P_{2} \\
\end{array}$ & $2 \mathrm{~s}^{2} 2 \mathrm{p}^{3}\left({ }^{2} \mathrm{P}^{\circ}\right) 3 \mathrm{~s}^{3} \mathrm{P}^{\circ}{ }_{2}$ \\
\hline 28 & 397.32 & 8.22 & O II & 23.44 & 26.56 & $3 \mathrm{~s}^{2} \mathrm{P}_{3 / 2}$ & $3 \mathrm{p}^{2} \mathrm{P}^{0} 1 / 2$ \\
\hline 29 & 407.58 & 16.84 & $\mathrm{O}$ II & 25.65 & 28.69 & $3 p^{4} D^{0} 5 / 2$ & $3 \mathrm{~d}^{4} \mathrm{~F}_{7 / 2}$ \\
\hline 30 & 411.92 & 14.9 & O II & 25.85 & 28.86 & $3 \mathrm{p}^{4} \mathrm{P}^{0}{ }_{5 / 2}$ & $3 d^{4} D_{7 / 2}$ \\
\hline 31 & 413.28 & 5.83 & O II & 25.83 & 28.83 & $3 p^{4} \mathrm{P}^{0} 1 / 2$ & $3 d^{4} P_{3 / 2}$ \\
\hline 32 & 418.97 & 10.96 & O II & 28.36 & 31.32 & $3 \mathrm{p}^{\prime 2} \mathrm{~F}^{0}$ & $3 d^{\prime 2} G$ \\
\hline 33 & 431.98 & 11.70 & O II & 28.82 & 31.69 & $\begin{array}{c}2 \mathrm{~s}^{2} 2 \mathrm{p}^{2}\left({ }^{1} \mathrm{D}\right) 3 \mathrm{p} \\
{ }^{2} \mathrm{P}^{\circ}{ }_{1 / 2}\end{array}$ & $2 s^{2} 2 p^{2}\left({ }^{1} D\right) 3 d^{2} S_{1 / 2}$ \\
\hline 34 & 433.68 & 17.92 & O II & 22.98 & 25.84 & $3 \mathrm{~s}^{4} \mathrm{P}_{3 / 2}$ & $3 p^{4} \mathrm{P}^{0} 3 / 2$ \\
\hline 35 & 436.92 & 10.57 & O II & 26.22 & 29.06 & $3 \mathrm{p}^{2} \mathrm{D}^{0}{ }_{5 / 2}$ & $3 d^{2} D$ \\
\hline 36 & 441.48 & 17.58 & O II & 23.44 & 26.24 & $\begin{array}{c}2 \mathrm{~s}^{2} 2 \mathrm{p}^{2}\left({ }^{3} \mathrm{P}\right) 3 \mathrm{~s} \\
2 \mathrm{P}_{3 / 2}\end{array}$ & $\begin{array}{c}2 \mathrm{~s}^{2} 2 \mathrm{p}^{2}\left({ }^{3} \mathrm{P}\right) \\
3 \mathrm{p}^{2} \mathrm{D}^{0}{ }_{5 / 2}\end{array}$ \\
\hline 37 & 444.81 & 3.27 & O II & 28.36 & 31.14 & $\begin{array}{l}2 \mathrm{~s}^{2} 2 \mathrm{p}^{2}\left({ }^{1} \mathrm{D}\right) 3 \mathrm{p} \\
{ }^{2} \mathrm{~F}^{\circ}{ }_{7 / 2}\end{array}$ & $2 \mathrm{~s}^{2} 2 \mathrm{p}^{2}\left({ }^{1} \mathrm{D}\right) 3 \mathrm{~d}^{2} \mathrm{~F}_{7 / 2}$ \\
\hline 38 & 446.62 & 7.03 & O II & 28.94 & 31.73 & $3 \mathrm{~d}^{2} \mathrm{P}_{3 / 2}$ & $4 f^{4} \mathrm{D}^{0}{ }_{3 / 2}$ \\
\hline 39 & 459.09 & 10.39 & O II & 25.66 & 28.36 & $3 s^{\prime 2} D_{5 / 2}$ & $3 \mathrm{p}^{\prime 2} \mathrm{~F}^{0}$ \\
\hline 40 & 464.18 & 15.43 & O II & 22.98 & 25.65 & $3 \mathrm{~s}^{4} \mathrm{P}_{3 / 2}$ & $3 \mathrm{p}^{4} \mathrm{D}^{0}{ }_{5 / 2}$ \\
\hline 41 & 464.91 & 21.13 & O II & 23.00 & 25.66 & $3 \mathrm{~s} 4 \mathrm{P}_{5 / 2}$ & $3 \mathrm{p}_{4} \mathrm{D}^{0}{ }_{7 / 2}$ \\
\hline 42 & 468.01 & 9.06 & $\mathrm{Zn} \mathrm{I}$ & 4.00 & 6.65 & $3 d^{10} 4 s 4 p^{3} \mathrm{P}_{0}^{\circ}$ & $3 \mathrm{~d}^{10} 4 \mathrm{~s} 5 \mathrm{~s}^{3} \mathrm{~S}_{1}$ \\
\hline 43 & 470.53 & 14.54 & O II & 26.25 & 28.88 & $3 \mathrm{p}^{2} \mathrm{D}^{0}{ }_{5 / 2}$ & $3 \mathrm{~d}^{2} \mathrm{~F}_{7 / 2}$ \\
\hline
\end{tabular}


Study of conditions of gas- discharge synthesis of Zinc oxide nanostructures under automatic UV-irradiation ...

Continuation of Table 1 .

\begin{tabular}{|l|c|c|c|c|c|c|c|}
\hline $\mathbf{4 4}$ & 472.21 & 18.28 & Zn I & 4.02 & 6.65 & $3 \mathrm{~d}^{10} 4 \mathrm{~s} 4 \mathrm{p}^{3} \mathrm{P}^{\circ}{ }_{1}$ & $3 \mathrm{~d}^{10} 4 \mathrm{~s}_{5} \mathrm{~s}^{3} \mathrm{~S}_{1}$ \\
\hline $\mathbf{4 5}$ & 481.05 & 21.35 & Zn I & 4.07 & 6.65 & $3 \mathrm{~d}^{10} 4 \mathrm{~s} 4 \mathrm{p}^{3} \mathrm{P}_{2}{ }_{2}$ & $3 \mathrm{~d}^{10} 4 \mathrm{~s}_{5} \mathrm{~s}^{3} \mathrm{~S}_{1}$ \\
\hline $\mathbf{4 6}$ & 491.16 & 5.60 & Zn II & 12.01 & 14.53 & $3 \mathrm{~d}^{10} 4 \mathrm{~d}^{2} \mathrm{D}_{3 / 2}$ & $3 \mathrm{~d}^{10} 4 \mathrm{f}^{2} \mathrm{~F}^{\circ}{ }_{5 / 2}$ \\
\hline $\mathbf{4 7}$ & 492.40 & 10 & Zn II & 12.02 & 14.53 & $3 \mathrm{~d}^{10} 4 \mathrm{~d}^{2} \mathrm{D}_{5 / 2}$ & $3 \mathrm{~d}^{10} 4 f^{2} \mathrm{~F}^{0} 7 / 2$ \\
\hline $\mathbf{4 8}$ & 513.11 & 3.64 & O I & 10.98 & 13.40 & $2 \mathrm{~s}^{2} 2 \mathrm{p}^{3}\left({ }^{4} \mathrm{~S}^{\circ}\right) 3 \mathrm{p}^{3} \mathrm{P}_{1}$ & $2 \mathrm{~s}^{2} 2 \mathrm{p}^{3}\left({ }^{4} \mathrm{~S}^{\circ}\right) 8 \mathrm{~d}^{3} \mathrm{D}^{\circ}{ }_{2}$ \\
\hline
\end{tabular}

In the plasma emission spectra of a bipolar, overstressed nanosecond discharge in air and a mixture of air with a small admixture of water vapor at a total pressure of the mixtures $\mathrm{p}=103.3 \mathrm{kPa}(\mathrm{d}=1 \mathrm{~mm})$, the main groups in the UV spectral range were two groups of intense lines of the atom and ion of zinc in the spectral range $200-280 \mathrm{~nm}$. The most intense in the first group of spectral lines were ion lines: 202.6; $206.2 \mathrm{~nm} \mathrm{Zn} \mathrm{II,} \mathrm{and}$ in the second group the lines of the zinc atom - 250.2; $255.8 \mathrm{~nm} \mathrm{Zn} \mathrm{I} \mathrm{[13],} \mathrm{which} \mathrm{does} \mathrm{not} \mathrm{correspond} \mathrm{to} \mathrm{the}$ data for the discharge in oxygen at its pressure $\mathrm{p}=$ $13.3 \mathrm{kPa}$ (Fig. 3. and the table).

This is probably due to a change in the type and pressure of the buffer gas, as well as the conditions for the formation of ectons in these discharges.

For an overstressed nanosecond discharge in oxygen in the spectral range 273-465, singly charged oxygen ions were the main source of radiation. On more intense spectral lines of the oxygen ion there were lines: 407.58 ; $411.92 ; 433.68 ; 441.48 ; 464.18 ; 464.91$ and $470.53 \mathrm{~nm} \mathrm{O}$ II. The energies of the upper energy levels for these spectral lines are in the range of $25-29 \mathrm{eV}$, which indicates a high temperature of electrons in the plasma, which was studied.

Comparison of the ratio of the effective cross sections of the spectral lines of the zinc atom: $\lambda=258.24$ and $267.05 \mathrm{~nm}$, taken from [20], with the experimental data showed that the ratio of the cross sections of direct electronic excitation of these lines at an electron energy $\mathrm{E}=30 \mathrm{eV}$ was - 5.6, and the ratio of the intensity of these spectral lines from our experiment was - 3.0. For the ratios of the corresponding cross sections of the spectral lines of the zinc atom at 481.05 and $472.21 \mathrm{~nm}$, 1.8 was obtained, and for the ratio of the intensities of these lines from the plasma of an overstressed nanosecond discharge, 1.1. As these relations do not coincide, it follows that direct electron impact in this experiment is not the main mechanism for populating the upper energy levels for the spectral lines of the zinc atom.

The main part of the energy of an overstressed nanosecond discharge is introduced into the cathode spot in the plasma phase, therefore, in the plasma bunch, it scatters, the energy is first introduced into the electronic component with the subsequent transfer of this energy from electrons to ions. Therefore, the possible mechanisms of the formation of excited zinc atoms, zinc and oxygen ions in the studied plasma can be determined by the processes of their excitation and ionization by electrons from metastable states, from the ground state of the corresponding ion and by the processes of dielectronic recombination [21]. The effective cross sections for the excitation of transition metal ions by electron impact are large and, for example, for zinc ions they reach $-10^{-16} \mathrm{~cm}^{2}$ [22]. The reason for the occurrence of such processes is the high concentration of electrons in the plasma of overstressed discharges of nanosecond duration with an ectonic mechanism of electrode sputtering, which reaches $10^{17} \mathrm{~cm}^{-3}$ [23].

\section{Conclusions}

Thus, it was found that at an oxygen pressure of $13.3 \mathrm{kPa}$ between zinc electrodes, at interelectrode distances of 2 and $7 \mathrm{~mm}$, a sufficiently uniform in space intense nanosecond discharge with a pulsed electric power of up to $0.6 \mathrm{MW}$ and an energy contribution to the plasma in one pulse was ignited.

The study of the spectral characteristics of plasma based on vapor-gas mixtures "zinc - oxygen" showed that the most intense were the spectral lines of singly charged ions of zinc and oxygen. The most probable processes of the formation of excited atoms and ions in a given discharge can be the reactions of excitation of zinc and oxygen ions by electrons and the processes of dielectronic recombination. Automatic irradiation of the substrate and film nuclei on the substrate by intense UV radiation of zinc and oxygen atoms and ions from a nanosecond discharge plasma is promising for influencing the electrical characteristics of synthesized films based on zinc oxide.

Shuaibov O.K. - Doctor of Physical and Mathematical Sciences, Professor at the Department of Quantum Electronics;

Minya O.Y. - Ph.D., Senior Researcher; Hrytsak R.V.- Ph.D., Senior Researcher; Malinina A.O. - Ph.D., Senior Researcher; Vatrala M.I. - Postgraduate at the Department at the Department of Quantum Electronics. 
[1] D.Z. Pai, D.L. Lacoste, C.O. Laux, Plasma Souces Sci. Technol. 19, 065015 (2010) https://doi.org/10.1088/0963-0252/19/6/065015.

[2] [O.K. Shuaibov, A.A. Malinina, A.N. Malinin, New gas-discharge methods for obtaining selective ultraviolet and visible radiation and synthesis of nanostructures of transition metal oxides. Monograph (Publishing house UzhNU "Hoverla" Uzhhorod 2019).

[3] V.F. Tarasenko, Runaway electrons preionized diffuse discharge (Nova Science Publishers Inc., New York, 2014).

[4] H.A. Mesiats, M.Y. Yalandyn, Advances in Physical Sciences 189(7), $747 \quad$ (2019). https://doi.org/10.3367/UFNr.2018.06.038354.

[5] E.Kh. Bakst, V.F. Tarasenko, Yu. V. Shut'ko, M.V. Erofeev, Quantum Electronics 42(2), 153 (2012) https://doi.org/10.1070/QE2012v042n02ABEH014795.

[6] A.K. Shuaibov, A.Y. Minya, Z.T. Gomoki, A.A. Malinina, A.N. Malinin, Surface Engineering and Applied Electrochemistry 56(4), 510 (2020) https://doi.org/10.3103/S106837552004016X.

[7] G.A. Mesyats, Usp. Fizich. Nauk. 165(6) 601 (1995) https://doi.org/10.1070/PU1995v038n06ABEH0000.

[8] [ T.E. Itina, A. Voloshko, Appl. Phys. B. 113, 473 (2013) https://doi.org/10. 1007/s00340-o13-5490-6.

[9] A. Shuaibov, A. Minya, A. Malinina, A. Malinin, R. Golomd, I. Shevera, Z. Gomoki, V. Danilo, Advances in Natural Sciences: Nanoscience and Nanotechnology 9, 035018 (2018) https://doi.org/10.1088/2043-6254.

[10] A.K. Shuaibov, A.Y. Minya, A.A. Malinina, A.N. Malinin, V. V. Danilo, M.Yu. Sichka, I.V. Shevera, Amerikan Journal of Mechanical and Materials Engineering 2(1), $8 \quad$ (2018) https://doi.org/10.11648.j.ajmme.20180201.12.

[11] A.Kh. Abduev, A.Sh. Asvarov, A.K. Akhmetov, R.M. Эmyrov, V.V. Beliaev, Technical Physics Letters 43(22), 40 (2017) https://doi.org/10.21883/PJTF.2017.22.45259.16874.

[12] V.V. Danilo, O. Y. Minya, O.K. Shuaibov, I.V. Shevera, Z.T. Gomoki, M.V. Dudich, Scientific herald of Uzhhorod University. Physics 42, 128 (2017) http://nbuv.gov.ua/UJRN/Nvuufiz 2017_42_17.

[13] [OK. Shuaibov, A.I. Minya, M.P. Chuchman, A.A. Malinin, V.V. Daniil, Z.T. Gomoku, Ukrainian Journal of Physics 63 (9), 790 (2018) https://doi.org/10.15407/ujpe63.9.790.

[14] A.K. Shuaibov, A.Y. Minya, Z.T. Gomoki, A.A. Malinina, A.N. Malinin, V.V. Danilo, Yu.Yu. Bilak, Ya.Ch. Kolozhvari HSOA Jounal of Biotech Research \& Biochemistry 3(1), 100005 (2020) https://doi.org/10.24966/BRB-0019/100005.

[15] G. Palani, K. Kannan, D. Radhika, P. Vijayakumar, K. Pakiyaraj, Physics and Chemistry of Solid State 21(4), 571 (2020) https://doi.org/10.15330/pcss.21.4.571-583.

[16] O.K. Shuaibov, O. I. Nalima, R.V. Hrytsak, A.A. Malinina, I.V. Shevera, M.I. Vatrala, Z.T. Gomoki, Physics and Chemistry of Solids 21 (4), 669 (2020) https://doi.org/10.15330/pcss.21.4.669-679.

[17] A.R. Striganov, N.S. Sventitsky, Tables of Spectral Lines of Neutral and Ionized Atoms (Atomizdat, Moscow, 1966).

[18] NIST Atomic Spectra Database Lines Form https:// physics.nist.gov/ PhysRefData/ASD/lines_form.html.

[19] S.I. Maksimov, A.V. Kretinina, N.S. Fomina, L.N. Gall, Scientific Instrumentation 25 (1), 36 (2015).

[20] Yu. M. Smirnov, Optics and Spectroscopy $104(2), \quad 159 \quad$ (2008) https://doi.org/10.1134/S0030400X08020021.

[21] R. Shyker, Y. Binur, A. Szokem Phys. Rev.A. 12(2), 512 (1975) https://doi.org/10.1103/PhysRevA.12.515.

[22] A.N. Gomonai, Journal of Applied Spectroscopy 82(1), 17 (2015) https://doi.org/10.1007/s10812-0150057-4.

[23] D. Levko, L.L. Raja, Physics of Plasmas 22, 123518 (2016) https://doi.org/10.1063/1.4939022. 
О.К. Шуаібов, О.Й. Миня, Р.В. Грицак, А.О. Малініна, М.І. Ватрала

\section{Дослідження умов газорозрядного синтезу наноструктур оксиду цинку при автоматичному УФ - опроміненні підкладки плазмою}

ДВНЗ «Ужгородський начіональний університет», Ужгород, Україна, alexsander.shuaibov@uzhnи.еdu.иа

Приведено спектроскопічні характеристики біполярного, перенапруженого розряду наносекундної тривалості між електродами 3 цинку в кисні при тиску $\mathrm{p}\left(\mathrm{O}_{2}\right)=13.3$ кПа. В процесі мікровибухів неоднорідностей на робочих поверхнях електродів в сильному електричному полі в розрядний проміжок вносяться пари цинку. Це створює передумови для утворення молекул і кластерів оксиду цинку в плазмі та синтезу тонких острівкових плівок оксиду цинку, які можуть осаджувались на діелектричній підкладці, встановленій поблизу від центру розрядного проміжку.

Спектральні характеристики розряду досліджувались 3 центральної частини розрядного проміжку величиною 2 мм. Встановлено основні збуджені складові плазми парогазової суміші на основі цинку і кисню при високих значеннях параметра E/N (де E - напруженість електричного поля; N- сумарна концентрація часток в плазмі), які при осадженні за межами розрядної плазми можуть приводити до утворення тонких наноструктурованих плівок на основі оксиду цинку.

Ключові слова: перенапружений наносекундний розряд, кисень, цинк, спектр випромінювання, плазма. 